BATTY

UNIVERSITY

Griffin, B. (2016) '"Bad roads will absolutely nip in the bud the new development": cycling tourism in Ireland in the late nineteenth and early twentieth centuries', in Lane, L. and Murphy, W., eds. Leisure and the Irish in the nineteenth century. Liverpool: Liverpool University Press, pp. 187-206.

Official publisher site: https://liverpooluniversitypress.co.uk/products/60445

\title{
ResearchSPAce
}

http://researchspace.bathspa.ac.uk/

This pre-published version is made available in accordance with publisher policies. Please cite only the published version using the reference above.

Your access and use of this document is based on your acceptance of the

ResearchSPAce Metadata and Data Policies, as well as applicable law:-

https://researchspace.bathspa.ac.uk/policies.html

Unless you accept the terms of these Policies in full, you do not have permission to download this document.

This cover sheet may not be removed from the document.

Please scroll down to view the document. 


\section{'Bad roads will absolutely nip in the bud the new development': Cycling tourism in Ireland in the late nineteenth and early twentieth centuries Brian Griffin}

Cycling witnessed a remarkable growth in popularity in Ireland in the late nineteenth and early twentieth centuries. At first, in the 1860 s, the pastime was participated in by a tiny number of individuals, who rode crude and unwieldy velocipede bicycles that were propelled by the riders pushing pedals on the front wheels. The fact that such machines were nicknamed 'boneshakers' provides a good insight into how uncomfortable an experience it was to ride these bicycles. The introduction of the high-wheeled 'ordinary' or 'pennyfarthing' bicycle in the early 1870s quickly rendered the velocipede obsolete and led to an increase in cycling's popularity, especially amongst young middle-class men; the introduction of the tricycle later in the decade meant that many less adventurous men, as well as some women, could also take up the new pastime. The invention of the chain-driven safety bicycle in the mid 1880 s, along with the introduction of the pneumatic tyre in 1889, sparked off a dramatic cycling revolution in the 1890s: by the latter decade's end, although cycling still remained a mainly middle-class activity, it was a genuinely popular phenomenon, rather than the niche pastime that it had been in the $1860 \mathrm{~s}^{1}{ }^{1}$ One of the significant ways in which cyclists enjoyed their hobby was by undertaking cycling tours in the Irish countryside.

The topic of tourism in the nineteenth and early twentieth centuries is one that has attracted the attention of a number of historians of leisure in Ireland in recent years. Ireland attracted tourist visitors throughout the eighteenth century and in the decades before the Great Famine, many of whom published accounts of their impressions of the country. ${ }^{2}$ Ireland became an even more popular tourist destination in the post-

\footnotetext{
${ }^{1}$ For a more detailed overview of these developments, see Brian Griffin, Cycling in Victorian Ireland (Dublin, 2006).

${ }^{2}$ For useful guides to much of this material, see John McVeagh, Irish travel writing: a bibliography (Dublin, 1996) and C. J. Woods, Travellers' accounts as source material for Irish historians (Dublin and Portland, Or., 2009). Excerpts of travellers' accounts may be found in John P. Harrington, The English traveller in Ireland: accounts of Ireland and the Irish through five centuries (Dublin, 1991) and Glenn Hooper, The tourist's gaze: travellers to Ireland, 1800-2000 (Cork, 2001).
} 
Famine decades, particularly as the expansion of the railway in this period meant that tourists could penetrate further into the country, and at greater ease, than had been the case before the Famine. The railway companies, aware of the potential profits to be made from developing tourism, made considerable efforts to cater for tourists' comfort - and to attract their custom - by building hotels at popular tourist destinations such as Killarney, Kenmare, Galway, Clifden, Bundoran and Rostrevor, to name just a few. ${ }^{3}$ As Donal Horgan points out, referring to the post-Famine decades, although the Victorians did not 'invent' tourism in Ireland, 'they certainly were the first to lay the foundations of today's industry. This was the period which saw the development of hotels, an efficient transport network in the form of railways and, of course, that ubiquitous symbol of tourism worldwide - the guidebook' ${ }^{4}$

While much work has been done on investigating the tourist boom in lateVictorian and Edwardian Ireland, one of its neglected topics is that of cyclist tourism. In Horgan's pioneering work, the cycling tourist gets only a brief reference, in which readers are told that 'The advent of touring clubs helped to further popularize the bicycle and, in turn, started to change the focus of tourism': 5 the nature of this change of focus is not spelt out in his text. A mere three bicycle tours in the period under study merit a mention in C. J. Woods's guide to travellers' accounts, ${ }^{6}$ while the subject of the cycling tourist is overlooked by Glenn Hooper ${ }^{7}$ and also by Irene Furlong's recent study of the development of the Irish tourist industry from the $1880 \mathrm{~s}$ to the $1980 \mathrm{~s} .{ }^{8}$ Irish historians have devoted more attention to tours that were undertaken in the first decade of the twentieth century in motor cars and charabancs than those that were undertaken on bicycles, ${ }^{9}$ even though motoring tourists constituted a tiny fraction of the overall tourist traffic in the period, and certainly a much smaller proportion than that represented by cycling tourists. The only study of cycling tourism in the period is a short article by K. J. James, a brief but nevertheless

\footnotetext{
${ }^{3}$ Donal Horgan, The Victorian visitor in Ireland: Irish tourism 1840-1910 (Cork, 2002), pp 26, 39, 86, 97-8, 100.

${ }^{4}$ Horgan, The Victorian visitor in Ireland, p.11.

${ }^{5}$ Horgan, The Victorian visitor in Ireland, p. 27.

${ }^{6}$ Woods, Travellers' accounts, p. 24.

${ }^{7}$ Hooper, Tourist's gaze.

${ }^{8}$ Irene Furlong, Irish tourism 1880-1980 (Dublin and Portland, Or., 2009).

${ }^{9}$ Patrick Flanagan, Transport in Ireland 1880-1910 (Dublin, 1969), pp 16-9, 24-9, 32-5; Bob Montgomery, An Irish roadside camera: Ireland's early motorists and their automobiles - the pioneering years 1896-1906 (Dublin, 1997), pp 27, 29, 51-5, 106-14.
} 
welcome first attempt at discussing the subject. ${ }^{10}$ This essay aims to address the relatively neglected topic of cycling tourism in Ireland in the late nineteenth and early twentieth centuries, by paying particular attention to the efforts that were made by tourism promoters to facilitate tourists who wished to undertake cycling holidays in the country. Just as hoteliers, publishers, railway companies and others in the travel sector made conscious efforts to develop an Irish tourist infrastructure in the decades before the cycling boom, many entrepreneurs, recognising the potential profits to be made from cycling holidaymakers in the late-Victorian and Edwardian periods, also went to considerable lengths to cater for the comfort of the cycling tourist, often working in partnership with various cyclist organisations to attain this goal. Road surfaces were improved with cycling tourists in mind, finger posts were erected to help them to navigate, guide books were written to aid them on their journeys, hotels were spruced up for them and hoteliers provided better value for them: the changes that were introduced to meet the needs of cycling holidaymakers constituted an important additional element to Ireland's tourist infrastructure in this period. An investigation into this topic not only offers significant insights into the cycling world of this era, but also throws new light on a relatively neglected aspect of the history of the Victorian and Edwardian Irish leisure industry.

Although much of the rhetoric produced by Irish cycling enthusiasts stressed the utility and efficiency of the tricycle and bicycle as modes of transport, as well as the health benefits to be derived from cycling, from an early stage the opportunities which cycling offered for the enhancement of people's leisure activity were also recognised. Indeed, as early as 1868 Richard Edward Brenan, a post office employee in Dungarvan, went on the first documented cycling holiday in Ireland - a trip which started in Dungarvan and included Youghal, Midleton, Queenstown, Cork, Ballincollig, Blarney and other Munster towns. ${ }^{11}$ Brenan cycled alone on this pioneering occasion, and his solo trip was far from unusual in the early decades of Irish cycling. Most of the cycling holidays that were undertaken in Ireland in the

\footnotetext{
${ }^{10} \mathrm{~K}$. J. James, "We were tired of touring on the ordinary lines": Irish cycling holidays at the turn of the $20^{\text {th }}$ century' in Glen Norcliffe (ed), Cycle history 17: proceedings of the $17^{\text {th }}$ international cycling history conference, York, Ontario, Canada, 6-7 July 2006 (San Francisco, 2007), pp 77-83.

${ }^{11}$ Griffin, Cycling, p.24.
} 
1870 s and early to mid 1880 s were undertaken either by solitary cyclists ${ }^{12}$ or by cyclists travelling in small numbers, usually in pairs. ${ }^{13}$

Many of the relatively small number of Irish cycling clubs in this period went on regular day runs into the countryside, but lengthier holiday trips of several days duration were not a regular feature of these clubs' activities. A number of Belfast clubs, such as the Windsor, Rugby, Richmond and Northern clubs, occasionally went on weekend holiday trips in the early and mid 1880s, especially over the Whit holiday period. ${ }^{14}$ The Dublin University Bicycle Club was the first Dublin cycling club to undertake Whit weekend holiday tours in these years; other contemporary Dublin clubs who occasionally organised weekend holiday cycling trips included the Eglinton and the Irish Champion clubs. ${ }^{15}$ The first Irish cycling club whose principal purpose was touring was the Ohne Hast club, founded in Dublin in 1886; cycling clubs with similar interests in touring were founded in the 1890s in Midleton, Nenagh and Longford. ${ }^{16}$ In addition to the holiday trips undertaken by a small number of cycling clubs, tours were also occasionally organised for readers of the Irish Cyclist and their friends by the newspaper's editor, R. J. Mecredy, to destinations such as Kerry, Connemara and Ulster. ${ }^{17}$ For Irish and other readers, published accounts of such trips, which often included illustrations of amusing or colourful episodes (see illustration 1), probably added to the appeal of cycling holidays. ${ }^{18}$

Although the evidence suggests that the pioneering cycling tourists generally enjoyed their holiday trips in Ireland, nevertheless their negative comments regarding roads, road signage and hotel accommodation are recurring features in their accounts

\footnotetext{
${ }^{12}$ For accounts of holiday trips by cyclists who rode alone in these decades, see Bicycling: its rise and development, a text book for riders (London, 1874), pp 27-9; Bicycling News, 21 July 1876, 28 July 1876, 4 Aug. 1876, 1 Sept. 1876, 8 Sept. 1876, 15 Sept. 1876, 26 Apr. 1878, 16 Aug. 1878, 20 Sept. 1878, 25 Oct. 1878, 27 Dec. 1878; Wheel World, Nov. 1880, Dec. 1880, June 1883; Cyclists' Touring Club Monthly Gazette, Apr. 1884.

${ }^{13}$ For accounts of holiday trips by pairs of cyclists, see Belfast News-Letter, 19 July 1877; Bicycling News, 21 Dec. 1877, 28 Dec. 1877, 29 Nov. 1878; Bicycling World, 24 Mar. 1882, 31 Mar. 1882, 7 Apr. 1882, 21 Apr. 1882, 28 Apr. 1882, 16 June 1882; Wheel World, Aug. 1886, Oct. 1886.

${ }^{14}$ Belfast News-Letter, 15 May 1883, 27 May 1885; Irish Cyclist, 4 Aug. 1886.

${ }^{15}$ Wheel World, June 1882, Sept. 1882.

${ }^{16}$ Griffin, Cycling, p. 152.

${ }^{17}$ R. J. Mecredy, The 'Irish Cyclist' tour to Connemara (Dublin, 1887); idem, The 'Irish Cyclist' third annual tour (1888) through the North on a ten-in-hand (Dublin, 1888); idem, Health's highway (Dublin, 1909), pp 17-25; Freeman's Journal, 3 Aug. 1886; A. J. Wilson, Two trips to the Emerald Isle (Dublin, 1888), pp 16-57.

${ }^{18}$ For example, Grace Denison, an American, was inspired to go on a cycling holiday in Ireland in 1893, along with her husband, after reading a newspaper account of the Ohne Hast touring club: Christina E. Dando, 'Riding the wheel: Selling American women mobility and geographic knowledge' in ACME: An International E-Journal for Critical Geographies, vol. vi, no. 2 (2007), pp 186-7.
} 
of their holiday experiences. Indeed, in the earliest account by a British cyclist holidaymaker in Ireland of which the author is aware, which was written in 1874, the atrocious state of roads in various parts of Ulster is frequently stressed. ${ }^{19}$ One disgruntled English tricyclist, after enduring what he considered the worst stretch of road in Ireland, the eleven miles between Youghal and Killeagh, stated in January 1884 that 'If I had been Lord Spencer I am quite sure I should have "reasonably suspected" the whole of the grand jury for the county of Cork, the county surveyor, and the contractor, and have sent them all to Kilmainham for at least three calendar months' ${ }^{20}$ In September 1885 another English cyclist, J. S. Whatton, remarking on the poor state of the main road from Dublin to Belfast, stated that 'the veriest sheeprun in Great Britain would be preferable'. ${ }^{21}$ While it would be an exaggeration to say that all Irish roads were poorly maintained, as some cyclists commented favourably on the condition of some roads, especially those in Connemara, ${ }^{22}$ nevertheless it was generally accepted that roads in Ireland were in an appreciably worse condition than those in Britain. The Irish Wheelman remarked in 1896 that:

Our Irish roads recall most vividly the barbarism of the days when Finn Ma Coull reigned in Ireland, and ere St Patrick banished the snakes from this country. If the ancient Milesian hero came to life again he would probably turn his attention to the highways, as he proved himself to be an able engineer by building the Giant's Causeway, and our patron saint, if his labours had been bestowed upon the present day, would undoubtedly banish the road contractors and surveyors of Ireland. ${ }^{23}$

According to a Wexford cyclist in 1897, there were better roads in Madagascar villages than those in her native county, to where, allegedly, strangers travelled for miles just to see how bad they were. ${ }^{24}$ Such was the poor condition of roads in much of Ireland, that tourists often followed the example of local cyclists and took to the footpaths in rural areas, rather than risk their necks by riding on the dangerous roads ${ }^{25}$

\footnotetext{
${ }^{19}$ Bicycling: its rise and development, pp 27-8. According to Cycling, this account was the first recorded 'attack' on Ireland by a British cyclist: Cycling, 1 Dec. 1900.

${ }^{20}$ W. H. Duignan, 'Ireland from a tricycle', Wheel World, Jan. 1884.

${ }^{21}$ Irish Cyclist, 30 Sept. 1885.

${ }^{22}$ Bicycling News, 4 Aug. 1876; 'Through the West on wheels', Irish Cyclist Christmas edition, 1886.

${ }^{23}$ Irish Wheelman, 7 Apr. 1896.

${ }^{24}$ Letter from 'Mdlle. Up-to-Data' in Irish Cyclist, 17 Feb. 1897.

${ }^{25}$ G. W. Hurston and H. R. Stokes, Round the world on bicycles (Melbourne, 1890), p.272; T. H. Holding, Cycle and camp (London, 1898), p.163; Cycling, 5 Nov. 1898. Although most cyclists who went on cycling holidays rode their own machines, some travelled on hired cycles instead: Cycling, 28 May 1898; A. W. Rumney, A cyclist's note book (London and Edinburgh, 1901), p.77.
} 
- according to one English tourist in 1888, the Royal Irish Constabulary turned a blind eye to this transgression by touring cyclists. ${ }^{26}$

Tourists could try to avoid some of the worst roads by purchasing guidebooks that provided details not just of the sights that were worth seeing, but also of the road conditions in various localities. R. J. Mecredy was the most successful Irish publisher of such guidebooks. ${ }^{27}$ The Cyclists' Touring Club (C.T.C.), founded as the Bicycling Touring Club in Harrogate in 1879 to promote cycling holidays, also published its own set of Irish guidebooks in 1899 and 1900, which were written by R. T. Lang. ${ }^{28}$ C.T.C. and other cyclist tourists in Ireland often relied on Mecredy's meticulously compiled colour-coded maps and descriptions of road conditions. ${ }^{29}$ This is not surprising, when one considers the glowing review that Mecredy's work received in the C.T.C.'s official organ, in which readers were told that 'To recommend it to the intending tourist in the Green Isle is all but superfluous, ${ }^{30}$ and also the extreme lengths to which Mecredy went in order to produce his material, as outlined in his account of how he produced his road map of Connemara:

The colouring on my maps is simply meant to denote the quality of surface from a cycling point of view, irrespective of gradient or width of road. Until this map of mine was issued, there was no map of the Connemara district even approximately correct. I took the greatest possible care in its compilation. The roads were ridden by me personally on a tandem, the back rider taking notes from my dictation as to the condition of the surface, the nature of the gradients, etc., the position of the various hills and their length being carefully checked by cyclometer readings. The labour expended on this and my other similar maps was simply extraordinary, and could never have been justified by the results were it not that it was to me a labour of love. ${ }^{31}$

\footnotetext{
${ }^{26}$ See the illustration captioned 'Footpath riding' in Wilson, Two trips, unnumbered page.

${ }^{27}$ R. J. Mecredy, Mecredy's road book of Ireland (Dublin, 1892). See also idem, Cycling and pedestrian guide to the neighbourhood of Dublin (Dublin, 1891); idem, Mecredy's cyclists' map of the neighbourhood of Dublin (Dublin and London, 1891); idem, Mecredy's road map of County Donegal (Dublin, c.1899).

${ }^{28}$ R. T. Lang, Cyclists' Touring Club. Irish road book. (Part I. South) (London, 1899); idem, Cyclists' Touring Club. Irish road book. (Part II. North) (London, 1900). Lang's second book, which covered Ireland north of a line from Dublin to Galway, was compiled partly with assistance from cyclists who had holidayed in these parts of the country, who were asked to provide Lang with information about the routes that they had taken on their travels: Cyclists' Touring Club Gazette, Sept. 1898.

${ }^{29}$ Cyclists' Touring Club Gazette, Oct. 1897, Sept. 1898, Sept. 1909, Nov. 1910; Cycling, 21 May 1898, 10 Dec. 1898.

${ }^{30}$ Cyclists' Touring Club Gazette, Oct. 1897.

${ }^{31}$ Cyclists' Touring Club Gazette, Dec. 1904.
} 
Mecredy's works were considered to be so authoritative a guide for tourist cyclists that they were recommended by other guidebooks ${ }^{32}$ or extracts from them were simply republished verbatim in other guidebooks, such as John O'Mahony and Robert Lloyd Praeger's The sunny side of Ireland. ${ }^{33}$ In addition to Mecredy's guidebooks, and those of the C.T.C., a number of other guidebooks devoted part of their contents to offering advice to cyclists on tourist routes and sights in Ireland, ${ }^{34}$ a sure sign of the growing importance of the cyclist at the turn of the century to Ireland's tourist industry.

If cyclists became fed up with the poor state of the roads over which they had to travel, or if they had other reasons to skip to the next part of their itinerary, ${ }^{35}$ they could avail themselves of special rates offered to cyclists by various railway companies ${ }^{36}$ including free carriage of passengers' bicycles on the line between Cork and Macroom in 1899. ${ }^{37}$ By the late 1890s, it was common for Dubliners to avail of the excellent railway links between the capital city and Galway to go on weekend cycling holiday trips in Connemara. ${ }^{38}$ Most cycling tourists, however, preferred to eschew rail travel, preferring to explore parts of Ireland that were away from wellestablished tourist routes and the railway network. ${ }^{39}$

The virtual absence of signposts is often mentioned in cycling tourists' accounts of their travels in Ireland - according to W. H. Duignan, writing in November 1883, 'Travellers in Ireland are left to find their own way, and guide posts are unknown'. There was allegedly only one such post in County Carlow, 'the arms of which had long ago disappeared, and it was known for a hundred miles round as "the guide post". 40 The situation had scarcely improved some fifteen years later when,

\footnotetext{
${ }^{32}$ M. J. B. Baddeley, Ireland (part I). Northern counties including Dublin and neighbourhood (London, Edinburgh, Dublin and New York, 1909), unnumbered contents page.

${ }^{33}$ John O'Mahony and Robert Lloyd Praeger, The sunny side of Ireland. How to see it by the Great Southern and Western Railway ( $2^{\text {nd }}$ ed, Dublin, 1903), pp 278-90.

${ }^{34}$ For some examples, see C. P. Redmond, Beauty spots in the South-East of Ireland and how to see them by car and cycle (Dublin and London, 1901); Henry Robert Gall Inglis, The 'royal' road book of Ireland (Edinburgh, 1902); Black's guide to Ireland (24 ${ }^{\text {th }}$ ed, London, 1906), pp xvi-xvii; C. S. Ward, Ireland (part II). East, West and South including Dublin and Howth (5 $5^{\text {th }}$ ed, London, 1906), pp xviixxiii; Black's guide to Killarney and the South of Ireland (London, 1909), pp 117, 163.

${ }^{35}$ John Cooke, Handbook for travellers in Ireland $\left(5^{\text {th }}\right.$ revised ed, London, 1896), p. 11; Cyclists' Touring Club Gazette, May 1899.

${ }^{36}$ For the Great Northern Railway see Belfast News-Letter, 7 June 1897 and Irish Wheelman, 10 Aug. 1897.

${ }^{37}$ Cyclists' Touring Club Gazette, June 1899.

${ }^{38}$ See 'Saturday to Monday in Connemara', an account of a holiday weekend trip by six Dublin journalists, in Freeman's Journal, 9 Aug. 1898.

39 James, 'Tired of travelling', p.78.

${ }^{40}$ Duignan, 'Ireland from a tricycle', Wheel World, Nov. 1883.
} 
according to one source in 1898, there were probably less than 100 fingerposts in all of Ireland. ${ }^{41}$ Signposts were certainly rare at this time, to judge from the fact that Beatrice Cresswell, an English cyclist tourist, was told that the signpost that she saw in Douglas was the only one in Ireland. ${ }^{42}$ Relying on directions from locals was not always considered a more dependable alternative: A. J. Wilson and his wife, who spent their honeymoon tricycling around Ireland in June 1887, found that not only were Irish miles longer than English ones, but that they were 'very elastic, according to the estimation of distance by our various informants' ${ }^{43}$ As late as 1906 , British readers were warned by one guidebook that 'The Irish peasant, especially in the West, is as incapable of measuring distances as of telling his right hand from his left; both are equally impossible to him'. ${ }^{44}$ The frustration frequently felt by foreign tourists at the imprecise directions given by Irish guides is summed up well in a Cycling cartoon in July 1892, in which a lost English cyclist, after listening to convoluted directions from a local 'Hibernian', 'muttered something about having ballywell enough of it, as he turned to follow the direction given' (illustration 2).

Accommodation for cycling tourists also left a lot to be desired before the turn of the century: for example, a Belfast rider who went on a bicycling holiday in 1884 from Ulster to Munster, on visiting Killarney at the height of the tourist season and finding it swamped with American visitors, 'thought myself lucky in being domiciled for a couple of nights in the corner of a disused lumber room'. ${ }^{45}$ In the same year, a British cyclist stayed in a temperance hotel in Enniskillen, 'where, with filthy accommodation, uneatable food, and with no claim to the slightest degree of comfort, they charged me 5 per cent more than the usual hotel charges'. ${ }^{46}$ Another British cyclist recorded details of what was generally an enjoyable holiday trip to Kerry in 1888 , the sole exception being the experience of 'being fleeced right and left by every living soul at Killarney who could invent an excuse for levying blackmail upon us'; ${ }^{47}$ in the following year, the Irish Cyclist commented on how 'Irish hotel proprietors, with few exceptions, belong to the order of the Golden Fleece [...] They cannot resist

\footnotetext{
${ }^{41}$ Irish Tourist, July 1898.

${ }^{42}$ Beatrice Cresswell, 'Experiences in Erin', Cycling, 5 Nov. 1898.

${ }^{43}$ A. J. Wilson, 'An Irish outing, awheel', Outing, Aug. 1888. See also Cycling, 24 Oct. 1891, for an account of the astonishment felt by the 'Saxon tourist' at 'the extraordinary elasticity' of distances in Ireland, as estimated by peasant guides.

${ }^{44}$ Black's guide to Ireland (24 ${ }^{\text {th }}$ ed, London, 1906), p.xvi.

${ }^{45}$ Belfast News-Letter, 6 Sept. 1884.

${ }^{46}$ Cyclists' Touring Club Monthly Gazette, Apr. 1884.

${ }^{47}$ Wilson, Two trips, p. 45.
} 
the temptation of reaping a golden harvest when the opportunity offers, and thus they drive away all except the most unwary or careless' ${ }^{48}$ An American cyclist who stayed at Lisnaskea in 1893 was astounded to find that not only was he charged a shilling for a night's stay in a room there, but that he also had a to pay an additional threepence 'because I was a "furriner!" He found that 'The room was tolerably well furnished, but not very tidy, and the broken pane of glass admitted none too much fresh air to counteract the fumes of boiling cabbage which proceeded up the stairs all evening' ${ }^{4}$

The first organised moves towards attempting to improve conditions for cycling tourists in Ireland came in 1884, with the establishment in the country of Northern, Southern, Eastern and Western divisions of the Cyclists' Touring Club (C.T.C.): this body, formed in Britain in 1879 as the Bicycle Touring Club, had as its main raison d'être the promotion of cycle touring. A largely well-to-do outfit (one observer of its officers in Dublin in 1890 commented that they consisted of 'doctors, clergymen, barristers, solicitors in numbers'), ${ }^{50}$ it appointed officials known as chief consuls and consuls throughout the United Kingdom, who gave information to C.T.C. members about roads, restaurants, accommodation and places of interest in their localities. The organisation also negotiated rates for meals and accommodation with hoteliers and innkeepers for its members throughout the United Kingdom, as well as appointing workmen as recommended cycle repairers in each C.T.C. district. ${ }^{51}$

Initially, there were some sixty C.T.C.-approved hotels and inns in Ireland, ${ }^{52}$ but the special arrangements for cyclists did not meet with the full approval of either cyclists, hoteliers or innkeepers: the original standard charge for meals and accommodation was regarded as too low to entice the better-quality hotels from entering into the system, while many other establishments considered the cost to be too dear for their potential customers. Tourists often found that the charges in C.T.C.approved hotels in 'many of the touring centres' were exorbitant, and the accommodation 'indifferent', compared with what was available in nearby hotels. ${ }^{53}$ Members' dissatisfaction was also possibly heightened by an awareness of the better facilities that awaited cycling tourists abroad - according to the Irish Cyclist in 1890,

\footnotetext{
${ }^{48}$ Irish Cyclist, 17 Apr. 1889.

${ }^{49}$ J. Perry Worden, 'Touring in Europe on next to nothing', Outing, Sept. 1894.

${ }^{50}$ Irish Cyclist, 15 Oct. 1890.

${ }^{51}$ Griffin, Cycling, p.154.

52 Cyclists' Touring Club Monthly Gazette, July 1884.

${ }^{53}$ Wheelmen's Gazette, Apr. 1886; R. J. Mecredy and Gerald Stoney, The art and pastime of cycling (Dublin, 1890), p.108.
} 
a 'large proportion' of Irish cyclists went on touring holidays, most of whom holidayed at some stage in either England, Scotland or the Continent. ${ }^{54}$ A marked improvement in provision for C.T.C. members came with the introduction of a revised tariff system in 1895 , which allowed contracted inns and hotels to offer to C.T.C. members a minimum reduction of 12.5 per cent on their regular charges ${ }^{55}$ - this prompted more higher-class hotels to opt into the C.T.C. system, and for the organisation's largely middle-class members to feel that they were getting good value for their money. By April 1897, some 105 Irish hotels had contracted into the new system, eighty-five of which had not previously participated in it. ${ }^{56}$

These changes to the C.T.C.'s accommodation arrangements should be seen as part of a larger effort to open up Ireland to increased tourist traffic, including cyclists, which was inaugurated in the early 1890s by an English businessman, Frederick W. Crossley. In 1891 Crossley founded the Irish Tourist Development Association 'with the object of bringing together all those in the country who stood to benefit from its tourism potential', and he worked indefatigably with businessmen, influential peers, hotel managers and railway companies to sell his vision of Ireland as a tourist destination. His efforts gained considerable momentum in 1894, with the beginning of a monthly journal, the Irish Tourist, and the formation of the Hotel and Restaurant Proprietors' Association of Ireland, and in 1895, with the creation of the Irish Tourist Association. Support from Lords Lieutenant Houghton from 1893 to 1895 and Cadogan in 1896 gave further boosts to Crossley's propaganda efforts, which aimed to make members of the business community more aware of the potential financial benefits that could accrue from a better organised tourist industry, and also to improve the infrastructure on which a stronger tourist industry would depend. ${ }^{57}$

The need for these improvements was also heightened by a growing interest in Britain and further afield in Ireland as a potential cycling tourist destination, which was partly fed by a growing number of published accounts by cyclists of their

\footnotetext{
${ }^{54}$ Irish Cyclist, 22 Oct. 1890.

${ }^{55}$ Freeman's Journal, 10 Apr. 1895.

${ }^{56}$ Cyclists' Touring Club Gazette, Apr. 1897. The hotels included such well-known establishments as the Imperial and the Windsor in Belfast, the Northern Counties in Portrush, the Metropole in Dublin, the Butler's Arms in Waterville, and the Abercorn Arms in Strabane.

${ }^{57}$ Alastair J. Durie, 'The need for legislation to promote tourism: a cause that united all Irish politicians' in Brenda Collins, Philip Ollerenshaw and Trevor Parkhill (eds), Industry, trade and people in Ireland 1650-1950: essays in honour of W. H. Crawford (Belfast, 2005), pp 195-7; Furlong, Irish tourism, pp 19-27; James, 'Tired of touring', pp 77-8.
} 
enjoyable holidays in Ireland, ${ }^{58}$ and also by promotional articles that encouraged intending holidaymakers to consider taking their holidays awheel in the Emerald Isle. ${ }^{59}$ Killarney, a long-established tourist destination with Irish and foreign tourists alike, was an early beneficiary of the increasing interest in cycling tourism in Ireland. According to Munster Life in March 1897:

And by no one is Killarney more appreciated than the cyclist. He can make Killarney town his head quarters for a week, and without the least difficulty can find some fresh route to travel each succeeding day, with interest unabated, and only wondering how it is that such a number of glorious scenes - dewy dells, lovely magnificent mountains and verdant valleys - could be gathered within so small a compass. Yet, thus it is, and, mind you, the fact has got mooted from one corner of the globe to the other, so that as surely as the summer sun shines out each year so surely will the burly Englishman, the canny Scott (sic), the hardy Welshman, the calculating Yankee, aye, and the unspeakable Turk, the heathen Chinee, and the prim Japanese visit Killarney; and every mother's son among them, who has learned the art of cycling, brings his 'bike' along. ${ }^{60}$

Specific target audiences, such as British teachers, were singled out by some of the promotional material aimed at encouraging Irish cycling tourism. They were informed in July 1897 that Ireland 'offers an excellent vantage ground for cycling tours', ${ }^{61}$ and it is likely that teachers, who could afford to buy bicycles on easy-payment hire purchase systems and who had plenty of leisure time in the summer to devote to holiday touring, constituted one strand of the 'ever-increasing army of touring cyclists' said to be travelling in Ireland in the summer of $1898 .^{62}$

The numbers of this 'army' were boosted by the anglophobia that was widespread on the Continent during the Boer War, which made more British cyclists look to Ireland as a touring ground than had been the case heretofore ${ }^{63}$ and also by Queen Victoria's visit in 1900, which was prompted partly in recognition of Irish soldiers' service in the war in South Africa and which led to additional favourable

\footnotetext{
${ }^{58}$ For some of many examples, see Cycling, 3 Aug. 1895, 24 June 1899; Wheelwoman, 12 Dec. 1896; Cycling and Motor World, 10 Mar. 1897, 14 Apr. 1897, 12 May 1897, 7 July 1897; Irish Tourist, July 1898; Cyclists' Touring Club Gazette, Sept. 1898, May 1899, Oct. 1900; Holding, Cycle and camp. These accounts of cycling trips in Ireland were similar to narratives written by holidaymakers who enjoyed cycling holidays in Britain, the U.S.A and continental Europe: see Duncan R. Jamieson, 'Bicycle touring in the late nineteenth century' in Andrew Ritchie and Ron van der Plas (eds), Cycle history 12: proceedings of the $12^{\text {th }}$ international cycling history conference, San Remo/Pigna, Italy, 25 28 September 2001 (San Francisco, 2002), pp 68-75.

${ }^{59}$ Cycling, 14 November 1896, 21 May 1898, 30 July 1898; Cyclists' Touring Club Gazette, Dec. 1898; A. R. Quinton, 'Cycling in Ireland. From Dublin to Killarney', Leisure Hour (June 1899).

${ }^{60}$ Munster Life, 6 Mar. 1897.

${ }^{61}$ The Practical Teacher, July 1897.

${ }^{62}$ Irish Tourist, May 1898.

${ }^{63}$ Freeman's Journal, 24 Mar. 1900; Irish Athletic and Cycling Record, 12 Apr. 1900.
} 
publicity regarding Ireland as a tourist destination, including for cyclists. ${ }^{64}$ The fact that in 1900 the Rover bicycle company produced an advertisement aimed at selling its 'Imperial' machine to British cyclists touring in Ireland is further evidence of the growing popularity of Ireland as a cycling holiday destination (see illustration 3). ${ }^{65}$ Tourism promoters received a further boost from Ireland's hosting of the Gordon Bennett motorcar race in 1903: the C.T.C's official organ commented that various British and Irish newspapers contained so many 'charming' photographs of the course to be followed by the race drivers that thousands of cycling tourists were certain to ride along the course, both during and after the race, while E. W. Burke, an Irish correspondent to the newspaper, assured prospective cycling tourists that the race's route 'is full of interest to any lover of pretty rural scenery, and to the antiquarian and archaeologist'. 66

The last decade of the nineteenth and the first decade of the twentieth century therefore saw much greater publicly voiced concern for touring cyclists' comfort (especially, but not exclusively, foreign tourists' comfort) and tourist infrastructure. One commentator, outlining the needs of the typical British tourist, stated in 1896 that 'If he can conquer the fear that he will be shot by Moonlighters, or mutilated by gorilla-faced natives, and can be morally certain of a well-cooked substantial dinner and a comfortable bed, he will be as pleased to travel to Killarney as to Waterloo or Bingen' ${ }^{67}$ The Irish Cyclist's London correspondent made some of the same points, if in a somewhat less crude manner, when he pointed out that 'the Englishman's weak point is his stomach', and that:

The worst of most places in Ireland that are worthy of a visit is that the hotels are either prohibitive in their charges (except for persons of wealth and prize-fighters) or completely devoid of any pretensions to cleanliness and comfort. It is the respectable, clean, and comfortable hotel, with good food, well cooked, and the whole show run at live-and-let live charges, that is really wanted. ${ }^{68}$

The C.T.C.'s reformed arrangements with Irish hotels and inns, as well as the efforts of other interested bodies, went some way towards addressing the complaints of British cyclist tourists about sub-standard and overpriced accommodation.

\footnotetext{
${ }^{64}$ See E. G. Ruckles, 'Where the Queen is spending her holidays. Ireland as a cyclist's touring ground', Cycling, 21 Apr. 1900.

${ }^{65}$ Cyclists' Touring Club Gazette, Aug. 1900.

${ }^{66}$ Cyclists' Touring Club Gazette, May 1903, July 1903.

${ }^{67}$ Walter J. Farquharson, 'The coming of the British tourist', New Ireland, v, no. 6 (Aug. 1896), p. 343.

${ }^{68}$ Irish Cyclist, 8 May 1895.
} 
Accounts by British and other cyclists from the mid 1890s onwards suggest that, although Irish hotels did not quite measure up to the high standards expected by foreign visitors, their levels of cleanliness and comfort were nevertheless improved from previous years. ${ }^{69}$ The Irish Tourist of May 1898 commented approvingly on recent changes in Irish hotels:

If [one is] not too particular, the hotels generally will be found comfortable, and the people kindly and courteous, ever ready to welcome a visitor. During the past few years a marked improvement has taken place in the cleanliness and comfort of the hotels; greater attention is given to the cooking; bills of fare are more varied, and, in consequence, tourists, in general, and cyclists, in particular, grumble less of hotel discomforts.

It claimed that the days were gone when a waiter, when asked for poached eggs, would reply 'the divil a one he ever heard of; but, if his honour wished, he could have a nice piece of poached salmon'. By 1907, there were some 259 C.T.C.-approved hotels in Ireland, including twenty temperance establishments (the majority of which - twelve - were, unsurprisingly, in Ulster), as well as some 107 official C.T.C. bicycle repairers. $^{70}$

Table 1: C.T.C. hotels and bicycle repairers in Ireland, 1907

$$
\text { Hotels Repairers }
$$

$\begin{array}{lll}\text { Munster } & 92 & 24 \\ \text { Ulster } & 80 & 40 \\ \text { Leinster } & 57 & 33 \\ \text { Connacht } & 30 & 10\end{array}$

Ireland

Cork, with some 36 hotels, and Kerry and Donegal, with 20 each, had 29.3 per cent of the overall total of C.T.C. establishments between them, which gives a good indication of the main destinations to which cycling tourists headed; in contrast, Kildare, Meath and Longford contained a mere two such establishments each. These

\footnotetext{
${ }^{69}$ Cycling, 21 Mar. 1896, 16 Dec. 1899; Cyclists' Touring Club Gazette, Jan. 1904, Sept. 1909, Mar. 1910.

${ }^{70}$ Information from E. R. Shipton, Cyclists' Touring Club. Handbook \& guide (British \& Irish), containing lists of C.T.C. hotels and inns (licensed and temperance) (with particulars of the special tariff pertaining to each), farm and boarding houses, county lodgings, coffee taverns, consuls, repairers, etc., etc. 1907 (London, 1907), pp 209-20.
} 
latter counties were normally bypassed by tourists, whether they were cyclists or not indeed, in 1906 cyclists were positively encouraged by one travel guide to travel by train from Dublin to the West, rather than waste time in the Midlands:

The roads from Dublin across the full breadth of Ireland to Galway, Westport and Ballina are dull, and, for long stretches, dreary. Moreover, the places passed are generally of little or no interest, and comfortable hotels are few and far between. To be overtaken by foul weather, or by a mishap to the machine, might easily prove distinctly disagreeable, and our advice to the tourist is to use the rail to [travel to] the places named above. ${ }^{71}$

The C.T.C. hotels, then, were generally located where there was the greatest perceived need for them, and, as with other hotels, cyclist tourists were, on the whole, reasonably satisfied with the accommodation and other services that they provided. It is true that in 1909 one disgruntled tourist claimed that two C.T.C. hotels in Ireland 'turned out to be filthy holes', ${ }^{72}$ but this level of tourist dissatisfaction seems to have been unusual by that point. Even if Irish hotels fell short of the kind of standards that prevailed in Britain, British cyclists seem to have been willing to overlook this, particularly when they were received in a friendly and courteous manner, which seems to have been the general case. ${ }^{73} \mathrm{C}$. Edwardes, a British tourist who went on a cycling holiday in Wicklow in 1903, summed up this view when he wrote that the hotels in Roundwood 'are of the free-and-easy national kind, which beg you so amiably to condone their deficiencies and take note of their virtues, that in time you come to think moderately well of their Oirish cobwebs and spiders, and maculated linen and rickety furniture' ${ }^{74}$

One gains an insight into how relatively successful the C.T.C.'s provision for cycling tourists was perceived to be, by the fact that Arthur Griffith tried to gain similar privileges for the Cinn-Riain Irish National Cycle-Touring Club, membership of which was open 'to all Irishmen and Irishwomen who are proud of their country'. The Cinn-Riain club, of which Griffith was the captain, was founded at a meeting of the Celtic Literary Society in Dublin in April 1903; it promoted 'cycle-touring to all

\footnotetext{
${ }^{71}$ Ward, Ireland (part II). 1906, p.xxii.

${ }^{72}$ Cyclists' Touring Club Gazette, Nov. 1909.

${ }^{73}$ For some of the many examples of positive statements about Irish hospitality towards tourists, see Cycling, 10 Dec. 1898; Cyclists' Touring Club Gazette, Jan. 1904, Oct. 1908, Sept. 1909.

${ }^{74}$ Cyclists' Touring Club Gazette, June 1903.
} 
places of historic and scenic interest in the vicinity of Dublin and the adjoining counties'. ${ }^{75}$

Tourist promoters also used a number of strategies to try to improve Ireland's road infrastructure, and thereby boost tourist traffic in the country, including cyclist tourism. The crudest strategy was to pour scorn upon those held responsible for the poor state of Ireland's roads, in the hope of prompting change; initially, before their replacement by county councils in 1898, these were the grand juries, who were often regarded by the Irish Cyclists' Association (I.C.A.), the C.T.C. and many individual cyclists as disgracefully niggardly when it came to setting rates sufficient enough to maintain roads in suitable conditions for tricycle and bicycle traffic. ${ }^{76}$ In 'Avaunt, Tourists', R. J. Mecredy satirised the neglect of the grand juries and road contractors as a noble stance that was protecting Ireland from hordes of unwanted tourists:

Ireland for the tourist is the new salvation cry. The poor Irishry! - soon we will have to sing your requiem, and hide your bones beneath a cairn of guide books, a German band playing your caoine! The wretched survivors will be a despicable mongrely of Anglo-anythings - a smooth-tongued race of dish-wipers, and luggage carriers. Vulgar Cockneys, half-washed factory hands, conceited quilldrivers from every corner of Britain, will ruthlessly swarm over our holiest spots. 'Arry's latest music-hall drivvle will break the grand silence of Glendalough; lively Brums will play leap-frog over the tombs in Clonmacnoise; English evening papers can be bought at Vinegar Hill; the halfpenny 'comics' will increase the lunacy rate in every hamlet - and all this in the name of Progress![...] With this frightful prospect inevitable, it is cheering to notice that it is being unconsciously delayed by the grand juries and the road contractors. Bravely, my friends! With bad roads we will stave off the tender Sassenach. In boulders and ruts we have a national defence; we will not make smooth highways into the core of our nationality for the stranger to glide in by; we do not want our Ireland to be a peoples' garden; better poverty than tips. Ireland for the Irish! ${ }^{77}$

Other means of pressuring grand juries into improving their maintenance of roads included the Weekly Irish Times's suggestion in April 1897 that cyclist tourists should write letters to newspapers detailing the condition of roads in the districts that they had visited (as well as commenting on hotel accommodation). According to the newspaper, 'By this means, not only will the country at large be benefited, but the

\footnotetext{
${ }^{75}$ In the account of the founding of the Cinn-Riain Club that was published in Griffith's United Irishman, readers were informed that 'The cycling element can be of enormous service in promoting the National revival': United Irishman, 11 Apr. 1903.

${ }^{76}$ See details of petitions by Irish cyclists to grand juries to improve the condition of roads in Irish Cyclist, 3 Mar. 1886, 6 Oct. 1886; Sport, 24 Mar. 1894. In December 1888, some 51 Dublin road contractors had their payments stopped after legal representations were made by the I.C.A. in protest at the poor work that they had done on roads in the Dublin area: Irish Cyclist, 26 Dec. 1888.

${ }^{77}$ Irish Cyclist, 9 June 1897.
} 
power of cyclists, in their just demands for better roads and good hotel accommodation, will be greatly extended' ${ }^{78}$

In the same month a council meeting of the Irish Tourist Association, chaired by F. W. Crossley and supported by R. J. Mecredy, established the Irish Roads Improvement Association (I.R.I.A.), to pressurise grand juries into improving road provision, partly through publicity campaigns. The I.R.I.A. also demanded 'the general erection of finger posts at cross roads', and the erection of danger boards on hills that were considered dangerous to cyclists. ${ }^{79}$ By April 1898, an I.C.A. letterwriting campaign to county surveyors and grand jurors was credited with having prompted an improvement in the quality of road surfaces in the neighbourhood of Dublin, as well as a noticeable increase in signposts and danger boards there. ${ }^{80}$

After the replacement of grand juries with county, urban and rural district councils in 1898, tourism promoters switched the focus of their attention to the new administrative bodies, in order to prompt further improved infrastructure for cycling tourists. ${ }^{81}$ The Irish Independent urged cyclists to vote for county councillors who promised to support the purchase of steamrollers, reminding cyclists that 'they number scores of thousands' and that 'they can also assert, without fear of contradiction, that good roads will bring about a remarkable increase in the tourist traffic to this country' ${ }^{82}$ R. J. Mecredy, predicting a tripling of the number of cycling tourists in Ireland in 1900, but despairing that 'Bad roads will absolutely nip in the bud the new development', published the names and addresses of ten rural district councillors for the Rathdown district and urged readers to visit them personally and persuade them to vote for payments of between $£ 500$ and $£ 750$ to improve the local roads. ${ }^{83}$ The C.T.C. paid for the erection of danger or caution boards in some eight counties by March 1899, ${ }^{84}$ and was instrumental in pressurising the various publicly elected councils to erect between 230 and 250 fingerposts in County Dublin by March

\footnotetext{
${ }^{78}$ Weekly Irish Times, 10 Apr. 1897.

${ }^{79}$ Weekly Irish Times, 24 Apr. 1897; Freeman's Journal, 27 Apr. 1897.

${ }^{80}$ Constabulary Gazette, 2 Apr. 1898.

${ }^{81}$ For the example of members of the C.T.C. petitioning commissioners in Pembroke, Rathgar and Rathmines townships, see Freeman's Journal, 6 Sept. 1898, 6 Oct. 1898.

${ }^{82}$ Undated Irish Independent article in Cyclists' Touring Club Gazette, Nov. 1898.

${ }^{83}$ Freeman's Journal, 13 July 1900. See also Belfast News-Letter, 13 Aug. 1900, 15 Aug. 1900, 17 Aug. 1900, for discussions of the urgent need for action to ensure that the potentially lucrative cycling tourist market was not lost due to poor roads.

${ }^{84}$ Cyclists' Touring Club Gazette, Mar. 1899.
} 
$1900 .^{85}$ The I.R.I.A.'s executive council boasted in January 1904 that it 'may fairly claim that owing to the influence of the association there is at present a boom in steam-rolling' on Irish roads, and suggested that the adoption of steamrolling in Counties Antrim, Tyrone, Monaghan and Wexford was due to its pressure on councillors and county surveyors. The association printed and circulated gratis some 5,000 copies of Thomas Aitken's pamphlet, Good roads: how to make and how to maintain them to Irish county councillors and rural district councillors, as well as to every Irish county surveyor, and looked forward to the near future when every Irish county council would utilise steamrollers, scarifiers and stone-breaking machines to maintain the roads. ${ }^{86}$

The I.R.I.A.'s hopes were not fully realised in the first decade of the twentieth century - cycling tourists still encountered poor roads, ${ }^{87}$ and tourist promoters continued to agitate for better conditions on Ireland's highways. The most famous examples were the Irish roads congresses that were held in Dublin in 1910 and 1911, which were organised by R. J. Mecredy: ${ }^{88}$ these were credited with being 'largely instrumental' in transforming the quality of Irish roads in the second decade of the twentieth century. ${ }^{89}$ While one should not exaggerate the progress that had been made towards this end in the two previous decades, as the provision and maintenance of a decent road infrastructure remained a recurring concern of local government throughout the twentieth century, ${ }^{90}$ nevertheless the efforts of entrepreneurs, tourist promoters and cycling organisations in the late Victorian and Edwardian periods, as discussed above, went a considerable way towards fulfilling tourism promoters' dreams of an infrastructure that would facilitate, rather than obstruct, cycling tourism in the country. ${ }^{91}$ The improvements in the quality of hotel accommodation, roads and

\footnotetext{
${ }^{85}$ Freeman's Journal, 24 Mar. 1900.

${ }^{86}$ Irish Cyclist, 20 Jan. 1904.

${ }^{87}$ See the vivid examples in W. Fitzwalter Wray, A vagabond's note book (London, 1908), pp 129, 206, 217, 220.

${ }^{88}$ The Irish roads congress. Record of proceedings. Dublin, 1910 (Dublin, 1910); The second Irish roads congress. Record of proceedings, Dublin, 1911 (Dublin, 1911).

${ }^{89}$ Bob Montgomery, R. J. Mecredy: The father of Irish motoring (Garristown, 2003), pp 20-21.

90 For a wider discussion of the various services provided by various local government bodies in the twentieth century, see Mary E. Daly (ed.), County and town: one hundred years of local government in Ireland (Dublin, 2001); Diarmaid Ferriter, 'Lovers of liberty?': local government in 20th century Ireland (Dublin, 2001).

91 The days were long gone when fare that was described as 'dog biscuits' would be offered to cycling tourists, as allegedly happened to one English cyclist at Horn Head, Co. Donegal, during his 500-mile holiday cycling trip from Antrim to Sligo in June 1893: A. W. Rumney, Fifty years a cyclist (Penrith, 1927), p.21.
} 
Page 18 of 18

tourist information, amongst other reforms, which formed part of a more general transformation of the Irish tourism industry in these years, helped to ensure that the cycling holidaymaker became an important component of Ireland's tourism growth in the late nineteenth and early twentieth centuries. 